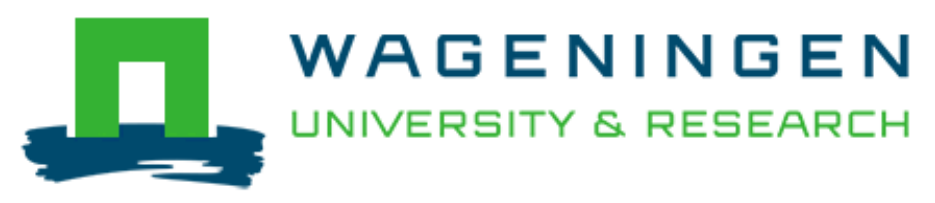

More than peanuts: Transformation towards a circular economy through a
small-wins governance framework

Termeer, C. J. A. M., \& Metze, T. A. P.

This is a "Post-Print" accepted manuscript, which has been Published in "Journal of Cleaner Production"

This version is distributed under a non-commercial no derivatives Creative Commons (c) (1) @ $\Theta$ (CC-BY-NC-ND) user license, which permits use, distribution, and reproduction in any medium, provided the original work is properly cited and not used for commercial purposes. Further, the restriction applies that if you remix, transform, or build upon the material, you may not distribute the modified material.

Please cite this publication as follows:

Termeer, C. J. A. M., \& Metze, T. A. P. (2019). More than peanuts: Transformation towards a circular economy through a small-wins governance framework. Journal of Cleaner Production, 240, [118272]. https://doi.org/10.1016/j.jclepro.2019.118272

You can download the published version at:

https://doi.org/10.1016/j.jclepro.2019.118272 
Cleaner Production

Elsevier Editorial System(tm) for Journal of

Manuscript Draft

Manuscript Number: JCLEPRO-D-19-06378R1

Title: More than peanuts: Transformation towards a circular economy through a small-wins governance framework

Article Type: Original article

Keywords: circular economy, governance, transformative change, small wins

Corresponding Author: Dr. Catrien Termeer,

Corresponding Author's Institution: Wageningen University

First Author: Catrien Termeer

Order of Authors: Catrien Termeer; Tamara Metze

Abstract: Governments across the world aim to accelerate the transition to a circular economy. A pressing question is to what extent and how they can influence transformative change, especially since a circular economy also inherently conflicts with norms underlying existing policies and regulations. Existing circular economy governance literature provide lists of barriers and develop targeted interventions without analyzing underlying mechanisms. This paper bridges this gap by presenting a coherent conceptual framework of continuous transformative change through accumulating small wins. Examples from Dutch Circular Economy Transition Program illustrate the arguments. Small wins are characterized by concrete results in terms of in-depth changes of moderate importance. In the long run, these small wins can amplify and accumulate into transformative change through non-linear mechanisms such as energizing, learning by doing, the logic of attraction, the bandwagon effect, coupling, and robustness. The related governance framework consists of three groups of interventions: 1) setting a provocative ambition; 2) identifying and appreciating small wins; 3) activating mechanisms through which smalls wins can accumulate in transformative change. The small-wins perspective embraces ambiguity, cherishes emerging change, replaces linear governance models by circular systems thinking, and provides insights about how small wins accumulate. First observations indicate that, although the small-wins perspective intuitively makes sense to governance actors, it clashes with the rather unrealistic expectations about governing transitions in rapid, radical, and top-down/linear ways. Hence, governing the acceleration of a linear to a circular economy, requires the transformation of the linearly organized governance system itself. 
More than peanuts: Transformation towards a circular economy through a small-wins governance framework

C.J.A.M. Termeer (corresponding author)

Professor at the Public Administration and Policy group, Wageningen University and Research. P.O. Box 8130, 6700 EW Wageningen, the Netherlands. T +31317482907. katrien.termeer@wur.nl

T.A.P. Metze

Associate Professor at the Public Administration and Policy group, Wageningen University and Research. P.O. Box 8130, 6700 EW Wageningen, the Netherlands.

tamara.metze-burghouts@wur.nl 


\section{More than peanuts: Transformation towards a circular economy through a small-wins governance framework}

\section{Introduction}

The circular economy (CE) concept has gained considerable traction over the past decade. It inspires a variety of actors through the paradigm of replacing end-of-life linear economic models by circular ones; it aims to reduce, reuse, recycle, and recover materials in production and consumption processes; it promises a win-win from an economic and value perspective; and introduces concepts such as eco-industrial parks and eco-cities (Galvão et al., 2018; Kirchherr et al., 2018). Recently, the concept has become a popular mantra among policymakers for addressing contemporary sustainability challenges (Blomsma and Brennan, 2017). Various governments and supranational bodies have developed ambitious policy plans to enhance more circularity, such as China's 2009 "Circular Economy Promotion Law of the People's Republic of China", the EU's 2015 "Circular economy strategy", the Scottish 2015 "Making things last: Creating a more circular economy in Scotland", or the Dutch 2016 "A circular economy in the Netherlands by 2050" (Lieder and Rashid, 2016; Geissdoerfer et al., 2017; Su et al., 2013; Domenech and Bahn-Walkowiak, 2017; Whicher et al., 2018).

Through its focus on closing loops, CE is at odds with many norms, logics and routines underlying the linear economy (Stahel, 2016). As a consequence, realising CE ambitions does require fundamental technological changes and changes at the level of practices, regulations, markets and networks (Kirchherr et al., 2018; Whicher et al., 2018;

Ghisellini et al., 2016; Hobson and Lynch, 2016; EC, 2015). This fundamental change at the system level is also referred to as a transition or transformative change (Grin et al., 2010; Hekkert et al., 2007). Both policy makers and scholars regard governance, and governmental interventions in particular an important factor in realizing the CE transition (Kirchherr et al., 2018; Filho et al., 2016). Governments have adopted these ideas in their plans and explicitly try to influence developments that contribute to these transitions. The European Commission, for example, has formulated goals such as "supporting" (2015, p.1) or "accelerating" (2019, p.8) a transition to a CE.

However, the pressing question remains to what extent and how governments can contribute to transitions or transformative change, especially since the CE inherently conflicts with norms underlying existing policies and regulations (Korhonen et al., 2018; Kirchherr et al., 2017). Given these challenges, scholars have paid a lot of attention to identifying and classifying limits to CE, resulting in lists of institutional, regulatory, 
market, cultural, social, technological and professional barriers (De Jesus and Mendonça, 2018; Kirchherr et al., 2018; Rizos et al., 2015; Van Bueren et al, 2016). To tackle these barriers, academics assign a broad variety of intervention strategies to governmental and other governance actors, such as eliminating subsidies that favour linear products (Kirchherr et al., 2018); adapting taxation and financial incentives to favour circular investments (Kirchherr et al., 2018; Stahel, 2016 ); shifting towards circular public procurement (Stahel, 2016; Velenturf et al., 2018); raising awareness through communication programs (Stahel, 2016; Rizos et al., 2015); initiating platforms and information networks (Rizos et al., 2015); enhancing effective university-businessgovernment collaboration (Velenturf et al., 2018); replacing GDP by using 'resourcemiser' indicators (Stahel, 2016); investing in education and training (Stahel, 2016); issuing restrictive regulation, such as product bans or waste acts (Cardoso de Oliveira et al., 2019; Velenturf et al., 2018); requiring product standards and labels (Cardoso de Oliveira et al., 2019; Rizos et al., 2015); or extending consumer and producer responsibility (Velenturf et al., 2018). Jiao and Boons (2014) argue that this diversity of strategies indicates that the mechanism for policy intervention and facilitation of the CE is still unclear. This fits with the general policy literature that criticises the simplistic intervention logic of listing barriers and developing targeted interventions, without analysing underlying mechanisms (Biesbroek et al., 2014). Türkeli et al. (2018) also point to the lack of in-depth knowledge on governance of a transition to a CE through appropriate supporting mechanisms and incentives.

This paper aims to bridge this knowledge gap by a conceptualization of mechanisms of transformative change, and to use these insights to develop governance interventions to accelerate a CE. For this purpose, the paper proposes and elaborates the governance framework of transformative change through accumulating small wins (Weick, 1984; O'Connor and Keil, 2017; Termeer and Dewulf, 2018). This small-wins framework is rooted in theories on continuous change (Weick \& Quinn, 1999) and appreciative inquiry (Cooperrider and Whitney, 1999) from organization science, and in incrementalism (Lindblom, 1979) from policy science. Small wins are defined as concrete, completed, indepth changes (Weick, 1984). They can accumulate into transformative change through various non-linear propelling mechanisms (Weick and Quinn, 1999). The small-wins framework is promising for CE transitions as it cherishes emerging change and replaces linear governance models by circular systems thinking.

To date, the small wins concept has not been applied extensively to the domain of CE. This paper will elaborate the framework for $\mathrm{CE}$, analyse how it advances the governance debate, and show how it can be made relevant for policy practices. The paper is theoretical and exploratory. To support and illustrate our argument, we use the case of 
the Dutch CE Transition Programme. The ambition of the Dutch Cabinet is to realise a CE together with a variety of stakeholders, including many who represent innovative circular initiatives. The parties jointly developed transition agendas for five economic sectors: biomass and food, plastics, manufacturing, construction, and consumer goods. Government actors facilitated and monitored the process. After a formal response from the Dutch Cabinet, implementation started in June 2018. This programme provides an interesting empirical example of a national government aiming to facilitate a transition to a CE because it is applying traditional regulatory and policy incentives and restrictions as well as appreciating and facilitating societal and industrial initiatives. The illustrative case study is based on documents analysis, seven interviews, four participatory observations of feedback meetings with the public and private transition agenda leaders; and two workshops with the involved national policymakers to reflect on the small-wins perspective (see also Termeer and Dewulf, 2017). Our illustrative case study is limited to a brief and descriptive analysis of the program and a few examples of potential small wins.

\section{Continuous transformative change through accumulating small wins}

Transitions or transformational change, including a change toward a CE are increasingly discussed as a necessary societal response to contemporary sustainability challenges. (EC, 2015; Farla et al., 2012; Fischer and Pascucci, 2017; Hobson and Lynch, 2016; Loorbach et al., 2017; Nalau and Handmer, 2015; Singh and Ordonez, 2016).

In general, transformation is associated with three characteristics of change: it is indepth, system wide, and fast (Hobson and Lynch, 2016; Lachman, 2013; Levy and Merry, 1986; O'Brien, 2012; Termeer et al., 2017). In-depth change or second-order change is advocated to break through prevailing mind-sets, norms, and interests in order to radically transform existing practices (Argyris and Schon, 1996). It contrasts with superficial or first order change, that aims to do things better within the existing institutional logics and taken-for-granted frames of reference (Argyris and Schon, 1996; Metze et al., 2017; O'Brien, 2012). In the context of CE the prevalent assumption is that improving existing practices without altering the values, societal structures, cultures, and underlying world-views is deemed insufficient (Korhonen et al., 2018). Hobson and Lynch (2016) even argue that our society must be reshaped to facilitate a circular future. Institutional lock-ins and path dependencies impede in-depth change (Grin et al., 2010, Hekkert et al., 2007; Loorbach et al., 2017). Institutions are designed and negotiated in times that linear economy concepts dominated the discourse. Nowadays, they constrain circular choices. However, these institutions are difficult to change because they do not 
only reflect previous preferences and circumstances, but also interests and power configurations (Pierson 2004).

Transformative change is system-wide, meaning that it is inherently multi-dimensional, multi-component, multi-aspectual, and multilevel (Levy and Merry 1986). Change is thus not limited to specific products, single firms, or isolated neighbourhoods. This fits the assumptions of the innovation system approach (Hekkert et al., 2007) and the MultiLevel-Model (Geels, 2011). These approaches argue that changes at the level of innovation systems, regimes and landscapes are needed to facilitate in-depth change and make it irreversible. On the bases of an extended systematic literature review, Kircherr et al., (2017, p. 125) conclude that CE is associated with large-scale transformations as it operates "at the micro level (products, companies, consumers), meso level (ecoindustrial parks) and macro level (city, region, nation and beyond)". These levels are inherently connected. System-wide change is in particular crucial for an holistic concept as $C E_{\text {, }}$ whereby flows of materials and energy exceed process, organizational, sectoral and administrative boundaries (Stahel, 2016; Korhonen et al., 2018).

Transformation is often surrounded by impatience and pressure to solve urgencies quickly. Various sustainability transitions are qualified as too slow to keep, for example, global climate change within the targets, set by international agreements (Roberts et al, 2018). The urgency behind a transformation to a CE is based on a looming resource and ecological crisis (Hobson and Lynch, 2016). Characteristics associated with transformational change like revolutionary jumps (Levy and Merry 1986), or shock-wise disruptive changes (Loorbach et al., 2017) suggest that transformational change would achieve the desired amount of change in a short period of time. However, most CE scholars emphasise the long term perspective and the benefits for future generations (Kirchherr et al., 2017). Despite these long time horizons, these scholars also emphasize the need to benefit the current generation and to influence and accelerate the pace of change (Hekkert et al., 2007; Kirchherr et al., 2017; Loorbach et al., 2017; Roberts et al., 2018). The many papers on barriers to a $C E$, all depart form the idea that these barriers slow down change and thus need to be understood and overcome (Kirchherr et al., 2018).

To summarise, the CE debate generally results in a call to realise all three characteristics (in-depth, large scale, and quick) simultaneously. Although this might be an attractive proposition for policymakers, we argue that this call and its underlying assumptions hinder the development of a coherent framework for governance-interventions to facilitate transformative change. The small wins framework provides an alternative governance perspective by focusing on how transformational change can be shaped through accumulating series of small wins (Burnes, 2004; Haigh and Griffiths, 2008; 
Termeer and Dewulf, 2018; Termeer et al., 2017; Brown and Eisenhardt, 1997; Weick and Quinn, 1999). The advantages of this alternative perspective are based on three arguments (see also Termeer et al., 2017).

First, it follows Vermaak (2013), who argues that achieving in-depth, system-wide and quick changes simultaneously is virtually impossible because of the inherent trade-offs between them. In-depth change requires people to break through their routines, learn about new modes of behaviour and challenge existing cultures. This is not achieved overnight and cannot be enabled through rolling out a large-scale intervention (Weick and Quinn 1999), and is easier for individuals than for societies as a whole (Argyris and Schön, 1996). Moreover, large-scale changes are more visible and thus will experience more institutional lock-ins and power-based pressure to conform, which will hinder indepth change. The alternative and only way is to go for depth by organising small-scale, second-order change (Vermaak, 2013). Weick (1984) labels these radical steps of moderate importance small wins.

Second, small wins are transformational. They are often associated with incremental change, which is portrayed as shallow, partial, and slow (Nalau and Handmer, 2015; O'Brien, 2012; Rotmans et al., 2001). Some scholars even fear that incremental steps may result in new lock-ins that make it more difficult to address the real big problems with big solutions (Behn, 2002). With their theory of continuous change, Weick and Quinn (1999) take a different perspective. They argue that episodic change starts from the idea that there are short periods of planned fundamental changes situated within long periods of stability. In contrast, continuous change starts from the idea that organizations are continuously adapting, learning and improvising through small steps (Weick \& Quinn, 1999). In non-linear systems, small wins resonate and can amplify into large-scale change, altering regulatory, bureaucratic, financial, and technological institutions (Orlikowski, 1996). Moreover, continuous change through accumulating small steps is not necessarily slower than radical (top-down and episodic) change, because there will be less incentives to postpone actions. Small steps are also less prone to premature termination and less threatening for politicians, because they remain somewhat "under the radar" and "the stakes are reduced, which encourages the losers to bear their loss without disrupting the social system" (Weick, 1984, p.47). Lindblom (1979, p.520) argued that it might also be the fastest way: "Incremental steps can be made quickly because they are only incremental. They do not rock the boat, do not stir up the great antagonisms and paralysing schisms, as do proposals for more drastic change". In the CE context, Biedenkopf et al., (2019) convincingly show how the stepby-step Fairphone approach is transforming the smartphone sector. 
Third, the immense aspiration of realising transformative change that is concurrently indepth, system-wide and quick, may trigger dysfunctional levels of arousal (Weick, 1984). This is the social-psychological mechanism that the massive scale on which social problems are conceived, activates helplessness which diminishes the quality of thought, precludes innovative action, paralyzes people and causes frustration (Weick, 1984). It may result in transition stress. Stahel (2016) refers to this by pointing out that the fear of the unknown means that the CE idea has been slow to gain traction' (p. 435). The contra-productive effect of a too high level of arousal is Weick's main argument for introducing the concept of small wins (Weick, 1984). Small steps allow people to start with fewer preconceptions, thereby helping people to better understand and handle complexity and providing room for innovative tailored action (Weick, 1984; Vermaak, 2013). This psychological mechanism is resonated in the argument of appreciative inquiry in which investigators focus on existing positive traits and processes that people desire to accumulate as a key engine of change (Bushe, 2011).

\section{The small-wins governance framework}

The small-wins perspective has far-reaching consequences for facilitating transformative change and for the design of governance interventions. Continuous transformational change is emergent and it cannot be controlled by planned change efforts and requires a more modest repertoire of interventions. This view echoes with the general critiques about strategic niche-management approaches that put too much emphasis on planned, well-ordered, and consensual processes (Farla et al., 2012). It also fits the ideas of emergent or autonomous change, indicating that people, organisations, and networks are already involved in numerous adjustments to their social practices in response to ongoing sustainability challenges (O'Brien, 2012).

We have developed a governance framework that fits into this continuous transformative change perspective, consisting of three groups of interventions: 1) setting a provocative ambition; 2) identifying and appreciating small wins; 3) activating mechanisms through which smalls wins can accumulate in transformative change (see also Termeer and Dewulf, 2018).

\subsection{Setting a provocative ambition}

\subsubsection{Concept and indicators}

Having a direction is crucial to encourage people and to organize commitment. Too much and too little focus can paralyse people (Burnes, 2004). Therefore, the first intervention 
includes the definition of a provocative ambition that gives direction. Cooperrider and Whitney (1999) developed the provocative propositions concept, which provides characteristics that are helpful to identify what we have labelled 'provocative ambitions'. These characteristics include: represent a desired future; help people to stay on track without hindering innovativeness; stretch, challenge, and disrupt the status quo; and being grounded, meaning that the ambition is more convincing when available examples show that change is already happening (Cooperrider, 2002). Setting a provocative ambition will be contested in a political context with multiple stakeholders and high stakes. This contested character and - as a result thereof - the ambiguity of an ambition can be a driver for change (Bushe, 2001).

\section{[insert table 1 here]}

\subsubsection{Illustration of provocative ambition in the Dutch transition program}

The Dutch CE Transition Programme aims to develop a CE in the Netherlands by 2050 (Ministry of Infrastructure and the Environment, 2016). An interim objective is a 50\% reduction in the use of primary raw materials (minerals, fossil fuels, and metals) by 2030. In January 2017, 300 actors signed the National Agreement on the $\mathrm{CE}_{\text {, including }}$ industries, SMEs, environmental NGOs, unions, financial institutions, municipalities, ministries, and knowledge institutions. This agreement demonstrates that the ambition represents a desired future for many actors.

Its attractiveness derives from its positive framing and in particular the promise of combining environmental quality with economic prosperity and social equity. Its basic ideas, such as closing material loops, extending product lifecycles, innovative designs, sharing, and virtualising products have a strong intuitive appeal that give a feeling of meaningfulness (see also Korhonen et al., 2018; Zink and Geyer, 2017). Setting the concrete dates of 2050 and 2030 has increased the experienced urgency. The ambition is rather ambiguous, because what the CE entails is not strictly defined. However, to date, this ambiguity and broad scope seem to increase its attractiveness. It provides room for innovation and reinforces the commitment to further stretch, challenge, and disrupt the status quo. Finally, all the goals are illustrated by examples of CE initiatives, showing their grounding in existing practices.

\subsection{Identifying and appreciating small wins}

\subsubsection{Concept and indicators}


Next to setting a provocative ambition, governance actors can provide conditions to encourage people to meet these ambitions (Weick, 2000; Termeer et al., 2017). Very often these conditions do not take into account initiatives in society that may be small wins. These initiatives may go unrecognised, and, without recognition, may be hindered and never contribute to large-scale transformative change (Goodman and Dean, 1982). If policymakers do not recognise a small win, they risk to discourage the most innovative projects and persons, despite their perfect match with the original (provocative) ambitions (Weick, 2000). Therefore, the second group of governance-interventions includes the identification and appreciation of emerging small wins. Small wins must not be confused with the term best practice, because things can always be improved (Roe, 2016). The concept of small wins is further defined with five characteristics relevant to the CE (see table 2).

First, small wins refer to concrete results of moderate importance. These wins are lived experiences that go beyond nicely framed promises or creative ideas. They are mostly located at a micro or local level because on that level people effectively handle uncertainties and turbulence (Vermaak, 2013). The first small wins described in the literature were five water-pollution lawsuits by the Environmental Protection Agency

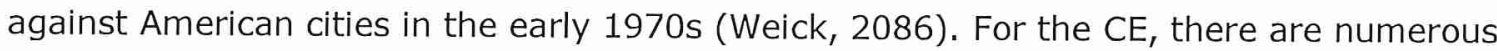
start-ups, pilots, and experiments, which are all potential small wins. Other initiatives such as circular contracts, citizen initiatives, or innovative legislation may also be small wins.

Second, a small win for CE should have a clear and shared narrative about its current and potential contribution to the circular ambition. As is the case for small wins in for example climate governance, small wins can be identified if they contribute to the set ambition and goals, such as limiting the increase in global mean temperature to $2^{\circ}$ Celsius (Urpelainen, 2013). The circularity indicators, developed by the Ellen MacArthur Foundation (2015), provide a helpful tool to estimate the current and potential contribution of an initiative to circularity. An alternative tool is the 'ladder of circularity' (Potting et al., 2017; Kirchherr et al., 2017). It distinguishes various gradations or levels for circularity: refuse, reduce, reuse, repair, refurbish, remanufacture, repurpose, recycle, recover energy. Although recycling and energy-recovery contribute to a $C E$, the final aim is to achieve higher levels of circularity. The advantage of this tool is that it provides room for improvement and prevents disqualifying and discouraging initiatives that contribute to recycling only. However, through their focus on products and technical cycles and materials, both tools are less directly applicable to social innovations.

Third, small wins differ from quick wins or low-hanging fruit, which are first-order changes by which people resolve simple issues and celebrate easy victories (Vermaak, 
2013; Weick, 1984). Small wins are related to in-depth change. This resonates with Kirchherr et al., (2018, p.229), who argue that the CE must be understood as a fundamental systemic change instead of a bit of "twisting the status quo" or a "quick win".

Fourth, small wins always have to overcome many barriers. These may include all types of barriers, mentioned in the introduction of this paper. Fischer and Pascucci (2017) argue that CE activities are inherently constrained by an institutionalised linear economy that is defended by existing power configurations. This implicates that each small win inevitably has to circumvent barriers, overcome resistance, alter constraints, or create conditions to tolerate tensions with existing institutions. If a small step is realised smoothly and without resistance, it may not be an in-depth change.

Finally, small wins connect technical and societal change. Firms, but also public actors, engaged in the CE transition face the challenge not only of intelligent product and process design, but also of arranging new collaboration and business relations (Fischer and Pascucci, 2017). Each small wins thus comprises one of the three types of CE transitions as identified by the Dutch Environmental Planning Agency (PBL, 2016): radically new technology enabled by adjusted social practices (e.g. bioplastics); socioinstitutional change making use of existing technologies (e.g. packaging-free shops); or radical socio-institutional change facilitated by new enabling technology (e.g. sharing economy).

\section{[Insert table 2 here]}

Identification of these small wins is not easy, as they typically emerge beneath the radar of public attention. Stahel (2016), for example, mentions that CE concepts have been successfully applied on small scales since the 1990s, but that few policymakers and researchers take notice. Weick (2000) points to the risk of the 'fallacy of centrality', meaning that actors who consider themselves central players become blind to surprises, because they react to what they thought would happen, rather than to what unfolds. As a consequence deliberate attention for the identification of small wins is required, by setting conditions that encourage an open mind and organise presence in a variety platforms, networks and localities.

\subsubsection{Illustration of the Dutch transition program}

The programme displays many examples that qualify as potential small wins. A recent study estimates that there are 1500 circular initiatives in the Netherlands (PBL, 2019). We selected four examples that qualify as a small win: a community initiative, a start-up, a public procurement pilot, and a regulation. 
WASTED is a community initiative to foster collaboration and waste separation in a neighbourhood of Amsterdam. For every bag of separated plastic, a digital WASTED token is offered, that can be exchanged for deals and discounts on goods and services at local shops and service providers. Bundles, a start-up founded in 2014, provides a circular laundry concept by selling washing cycles instead of washing machines, and providing customers an app that helps them reduce their laundry footprint and save on costs. The third example comes from Rijkswaterstaat (Dutch Public Works and Water Management Agency) that started a circular procurement pilot for leasing workwear by developing a performance-based contract with a market party, in which the supplier remains the owner of the clothing and the raw materials. The final example is the legal ban on free plastic bags in Dutch shops.

All four examples went beyond paper promises and show solid outcomes of moderate importance. WASTED has an increasing number of participants, Bundles has placed over 1000 of its washing machines to provide the washing cycles, Rijkswaterstaat leases workwear packages for 56 lock stewards for a two-season period, and the ban on free plastic bags is effective from 1 January 2016. They all contribute to a CE. To date only the ban on plastic bags for free has been evaluated and there is a reduction of plastic litter by $40 \%$ within one year, and an increasing number of consumers bringing their own bag to stores. Other examples do not have data to which the CE indicators can be applied.

The evaluation of the depth of change of each of the small wins, is context specific. In most Dutch towns, WASTED would not qualify as an in-depth change, given the already internalised practices of waste separation. However, in less flourishing neighbourhoods in the metropolitan area of Amsterdam, WASTED stimulated a more environmentally conscious neighbourhood by introducing a system that values the act of recycling. The Bundles initiative represents the most in-depth change by offering a service rather than products. The procurement pilot also hints at leasing of products instead of owning, but in a less radical way. Although a ban on free plastic bags is not as radical as an overall ban, it alters the behaviour of consumers and retailers.

These rather small steps all had to overcome serious barriers. The implementation of WASTED was difficult due to lack of funding and tensions with the highly regulated waste domain. An initial donation from a foundation; WASTED's embeddedness in a bigger NGO; and the energy and skills of many volunteers, helped to overcome the initial barriers. The small scale of the project convinced governmental actors to tolerate tensions with formal waste regulations. The Bundles' founder encountered enthusiasm for his concept and received some donations to develop it. Serious barriers were faced with long-term financing of the project, and the reallocation of ownership of the washing 
machines. Alternative ways of structuring long-term financing that are acceptable to the tax authorities are being developed with help of some experts. The small win of public circular procurement was blocked by endless debates on criteria and procedures. Starting with pilots was an effective way to overcome these barriers. Last but not least, the regulation prohibiting free plastic bags was debated over three years and caused many controversies between actors in the supply chain, members of parliament, and lobbying organisations. The failure of a covenant, public attention for the plastic soup, the European directive to reduce the use of plastic bags, and a left-wing minister helped policymakers to overcome all barriers and pass the regulation.

\subsection{Activating the right mechanisms}

\subsubsection{Concepts and indicators}

Single small wins will not result in a transformation to a CE. Therefore, the third group of governance-interventions, is to inquire which mechanisms make small wins accumulate. These insights can be used by governing actors to develop interventions that activate these mechanisms. We define propelling mechanisms as chains of events that reinforce themselves through positive feedback loops resulting in virtuous cycles that yield increasingly favourable outcomes (Garud \& Kumaraswamy, 2005; Termeer and Dewulf, 2018).

Many CE scholars emphasise the need to spread niche opportunities in order for systemic change to happen (Whicher et al., 2018). Some of them also refer to this dynamic accumulation process as a virtuous circle of bottom-up initiatives towards greener production (Ghisellini et al., 2016; Hekkert, 2007). We follow Wells and Nieuwenhuis (2018, p.450), who argue that Rogers' (1983) iconic diffusion model is too simplistic to reflect the CE reality. Other scholars also criticise the simple scale-up metaphors (see for example Ma et al., 2018). We define three kinds of amplifying effects on an initial small change: 1) upscaling: it becomes larger and more numerous, 2) broadening: it escalates its consequences and effects in other areas, or 3) deepening: it intensifies and becomes more radical (Garud and Kumaraswamy, 2005; Plowman et al., 2007; Van den Bosch and Rotmans, 2009).

On the basis of literature from mainly the field of organisational change science, Termeer and Dewulf (2018) have indicated some general propelling mechanisms: energising, learning by doing, the logic of attraction, the bandwagon effect, coupling, and robustness. We elaborate these mechanisms, illustrate them with insights from the CE literature (if attainable), and link them to governance intervention that can activate these mechanisms and thus accelerate transitions to a CE (see table 3). 
Energising means that the concrete outcomes and visible results of a single small win provide actors with the excitement that small wins are attainable, thereby encouraging them to look ahead for the next potential small win (Weick, 1984). The energising mechanism includes increased commitment to the initiative - "yes, it can" - as well as increased mutual trust - "yes, we can". A deliberate activation of energy heightens creativity and the courage to take innovative actions (Bushe, 2011). The CE literature often refers to bursts of enthusiasm in the various communities who achieve small wins (Farla et al., 2012; Kirchherr et al., 2018; Korhonen et al., 2018). However, it is hardly recognized as a mechanism that can be cherished and activated by governance actors in order to accelerate transitions. In the sustainability literature we found one example of governmental actors who energised actors and increased their commitment to environmental change, though framing results as success (O'Connor and Keil, 2017). Korhonen et al., (2018) noted that sometimes, scientific research seems to move more slowly than the practitioner community and its enthusiasm. That might also apply for policy makers. Caution is needed for collective disappointment, the opposite of enthusiasm, that easily results in vicious circles that are difficult to change (Hekkert et al., 2007). It fits the assumptions of the appreciative inquiry school (Cooperrider and Whitney, 1999) that a focus on problems and disqualification of current processes and people is counterproductive, and hinders in-depth change.

The learning by doing mechanism is based on the idea that the concrete results of small wins (1) uncover resources and barriers that were invisible before, (2) provide quick feedback on the effectiveness of strategies, (3) offer immediate insights into system reactions, and (4) encourage reflection on personal and other belief systems (Weick, 1984; Foster-Fishman and Watson, 2012; Kemp et al., 2007). As a consequence, each attempt to achieve a small win, whether it is successful or not, will result in new ideas. This learning mechanism is abundantly discussed in literature as the heart of transition processes (Hekkert et al., 2007). The CE literature also refers to this reinforcing cycle by showing how successful experimentation results in new experiments (Kirchherr et al., 2018). Besides the traditional Research \& Development instruments, governance interventions that aim to accelerate learning include enhancing network and exchange activities, such as communities of practices or science-business collaborations (Rizos et al., 2015; Velenturf et al., 2018). Above all, it requires governments to approach experiments by improvising, taking risks, seeing and using opportunities, and tolerating uncertainty and disappointments (Baez \& Abolafia, 2002).

The logic of attraction mechanism means that financial and human resources tend to flow towards winners (Weick, 1984). Moreover, positive results discourage the usual opponents and lower existing political and societal resistance (Weick, 1984). More 
generally, scholars emphasise the importance of supportive structures for actors who pursue systemic change but find themselves in a hostile environment (Farla et al., 2012). When influential actors, such as policymakers, advocate a small win, this creates credibility which catalyses attracting additional resources (Hekkert, et al., 2007). This positive evaluation should not be limited to words, but also visible in actions. Whicher et al. (2018), for example reflect this argument when they mention prestigious CE awards as an important governance mechanism. It is through the mechanism of the logic of attraction that minor targeted interventions such as circular public procurement, awards, or a small subsidy, accelerate transitions.

The bandwagon effect is a psychological phenomenon whereby people do something because other people are doing it (Behn, 2002). This mechanism resonates elements of the classic 'diffusion curve', with adopters and early majority (Rogers, 1983). Also when stakeholders engage in CE activities and create arrangements that circumvent barriers, they become examples for other stakeholders (Fischer and Pascucci, 2017). This effect relates to what Biedenkopf et al., (2019) call exemplary leadership. Hence, spreading the news is an important governance mechanism: "Telling, and re-telling of people's best of stories results in a wave of countervailing micro-narratives that combine, over time, to change the prevailing macro-narrative of the organization" (Bushe, 2011, p. 94). To date, the CE concept has sparked a lively interest mainly among sustainable development professionals, but has not reached the mainstream yet (Kircherr et al,. 2018). Current governance-interventions are mainly targeted to the in-crowd CE community, but small wins may also inspire others to see more concretely what an alternative economy would look like, and they may imitate or adopt it (Reay et al., 2006). Jiao and Boons (2014) refer to this as concepts that travel across spatial and temporal dimensions. However, it should not be forgotten that bad practice may be copied as well (Filho et al., 2016).

The coupling mechanism is based on the idea that small wins may also accumulate when they combine with other topics or ambitions across boundaries of policy systems, businesses and scales (Weick and Quinn, 1999). This mechanisms fits the observation that actors who support sustainability transitions often have other priorities than mitigating climate change or reducing waste (Roberts et al., 2018). The broad scope of CE enables linkages with many other policy priorities including city marketing, social coherence or the provision of local skilled job opportunities (McDowall et al., 2017; Stahel, 2016; Whicher et al., 2018). This holistic potential of CE collides with the silo structures of academia, companies and administrations (Stahel, 2016). Many suggested governance-interventions already aim to activate coupling mechanisms, such as bringing together complementary knowledge, managing interfaces, cutting across subsystem 
borders and superseding tunnel visons (Hekkert 2007), including a call for mainstreaming and policy integration (Candel and Biesbroek, 2016).

The robustness mechanism refers to reaching the point of no-return, whereby initiatives have become so numerous and legitimatised that turning back to the initial situation is impossible. This increased visibility can in turn create new sources thereby making it harder to dismantle (Roberts et al., 2018). Stahel (2016) refers to this as a tipping point, the moment when, for example, designing products for reuse has become the norm. However, arriving at this tipping point is difficult as barriers become bigger after the initial successes (Hekkert, 2007). Framing a small win as a pilot or experiment is a safe way to prevent premature termination, but hinders the robustness mechanism.

Governments can go beyond the pilot phase by rearranging existing policies as an answer to new solutions (Baez \& Abolafia, 2002). Finally, governments may institutionalize change in new formal regulations. Fischer and Pascucci (2017, p.28) refer to this as "bottom up effects on the formal institutional level", and mention the example of new regulations for ownership.

\section{[insert table 3 here]}

\subsubsection{Illustration of the Dutch transition program}

The small wins governance framework distinguishes three modes of accumulation that the propelling mechanisms can contribute to: upscaling, broadening, and deepening. Table 4 shows the meaning of these three modes for the four examples.

\section{[insert table 4 here]}

In the four examples the mechanisms of energising and learning by doing have had great impact. People talk with great enthusiasm about the initiatives. Success of initial experiments spurts bursts of ideas for new experiments, and none of the initiators stopped after the first success. The four examples all grew after the initial successes but still encounter difficulties: there are fewer subsidies for scale-ups than for start-ups; financial risks increase; and investments exceed existing capacities. Having a sparring partner within a governmental organisation, receiving subsidies for learning activities, or being part of a European network were considered helpful governance interventions that should also be available beyond the start-up phase. 
The logic of attraction and bandwagon mechanisms manifest themselves as strong mechanisms in the examples we explored for the Dutch CE policy. Small donations or explicit declarations of trust from powerful actors convinced other financial organisations to step in and thus overcome the "Catch 22 " logic that one needs money to make money. Once some key actors had signed a CE covenant, many others followed. Showcasing good examples and labelling some of them as iconic projects was an important governance-intervention. This activated both mechanisms but is not always enough to overcome barriers towards the next step. WASTED, for example, was showcased at the World Forum in Davos, resulting in more attention but not directly in more funding and support. Government can also activate both mechanisms, for example by leading by example. Circular procurement by the government or a modest form of regulating plastics can activate other organisations. However, discontinuity in procurement or other policies can also stop vulnerable acceleration processes.

The four explored CE small wins provided opportunities for coupling to other societal problems. WASTED is a good example of connecting sustainability challenges to local problems of exclusion, loneliness, unemployment, lack of social cohesion, competition between local retailers and multinationals, and so on. This coupling increased the durability and increased the chance of more radical change. This example also shows that it is better for government to try and integrate other societal issues into CE transitions than to develop separate social programmes to compensate for negative effects of CE policies.

Up till now, the transformative change in the four examples is not yet robust. We do not expect the Amsterdam neighbourhoods to separate their waste if they no longer receive tokens for it, nor consumers to ask a retailer whether they can lease a washing machine. Circular procurement is still in its pilot phase. The ban on free plastic bags has changed behaviour, but it is not yet so internalised that people will continue if the regulation is cancelled.

\section{Discussion}

This paper elaborated the small wins governance framework for accelerating a transformation to a CE. In this section we discuss how this framework contributes to the debate about the governance of CE.

The small wins governance framework bridges the gap in current literature between the lists of barriers to a transition on one hand, and unstructured sets of governance interventions on the other (see for example Biesbroek et al., 2014; Jiao and Boons, 
2014; Türkeli et al., 2018). It does so, by presenting a coherent framework of continuous transformative change through propelling mechanisms that make small wins accumulate. This framework theoretically underpins three groups of governance-intervention strategies: setting a provocative ambition; appreciating small wins; activating propelling mechanisms to upscale, broaden, and deepen small wins. These interventions do not target individual barriers but the underlying mechanisms. Following Biesbroek et al., (2014) the framework does not focus on mechanisms that explain impasses, but on mechanisms that explain acceleration. Hence, the framework offers a new understanding of how small wins accumulate and as such suggests innovative entry points for governance interventions.

This does not implicate that the proposed interventions are completely different from those referred to in the introduction, nor that these are limited to process interventions. In addition to many transition and network management authors (e.g. Grin et al, 2010; Kemp et al, 2007, Klijn and Koppenjan, 2016), who mainly focus on facilitating interactions, experimentation and learning, our framework also values and underpins the use of traditional tools of government, such as subsidies or legislation. However, all these interventions are more explicitly linked to the non-linear mechanisms that accelerate transformation to a CE as well as to the final ambitions of a CE. Therefore, the interventions can be more targeted and effective. This means, for example, that interventions to enhance learning won't be effective if they do not activate ongoing learning by doing mechanisms, or even worse, if there are no initial small wins for a CE at all. It also implicates that a subsidy that aims to activate the logic of attraction so that other investments will follow, will differ from a subsidy that focusses on learning by doing and thus aims to enable consecutive experiments.

In contrast to transition management authors (Kemp et al., 2007; Rotmans et al., 2001; Loorbach, 2014), who also acknowledge non-linearity and cherish emergent change, our framework is more radically embedded in a continuous change perspective. Hence, it does not perceive transitions as a change from one system to another via phases, including a period of nonlinear disruptive change and corresponding governance interventions. In addition, by following the ideas of appreciative inquiry, the current system is not completely disqualified as elements may be valuable, and the framework deliberately pays no attention to grand attempts to dismantle unsustainable regimes.

Recently, Kirchherr et al. (2017) identified 114 definitions of $\mathrm{CE}_{\text {I }}$ indicating that the $\mathrm{CE}$ means many things to different people. A specific advantage of the small-wins governance framework is that it embraces ambiguity as a driver for change. Korhonen (2018) resonates this idea: "The existence of various and conflicting views on CE should, therefore, not be used as an excuse for inaction...(it) helps in its understanding and 
provides a possibility to use CE in a constructive manner" (Korhonen, 2018, p. 549). As such, the concept of a CE displays characteristics of a boundary concept, as it sits at the boundaries of environmental and economic domains. As such it resonates and finds broad consent that enables linkages with various policy priorities including jobs, climate change, and inclusive growth (McDowall et al., 2017; Whicher et al., 2018; Metze, 2010). However, critiques have pointed out that an overall support for a CE could also indicate that it is not radical enough (Hobson and Lynch, 2016). This echoes with a more general critique that the CE is an "alternative growth discourse" and not an "alternative to growth discourse" Ghisellini et al., (2016, p.16). Consequently, the ambition for a CE could postpone tough decisions and risk a rebound by increasing overall production and consumption and therefore increasing environmental impact (Zink and Geyer, 2017). In our framework we therefore put extra emphasis on the 'having overcome barriers' characteristic of small wins: they can only be small wins - if there is experience of tension and conflict otherwise change has not been radical.

Our illustrative case shows abundant examples of CE initiatives in the Netherlands, of which many qualify as small wins. Mitchell et al. (2012) interpret the emergence of small wins as indicative of a broader societal-level momentum for change. However, our initial observations in the meetings and workshops with policymakers indicate that though the small-wins perspective intuitively makes sense to them, the potential of these small wins as seeds for transformative change are not fully deployed. This is also visible in the various policy documents (e.g. Ministry of Infrastructure and Watermanagement, 2019) that tend to use small wins as examples to underpin governmental arguments and ground their ambitions, rather than nurturing them as seeds of transformative change. Policy makers tend to put more effort into initiating new projects than into accumulating existing ones. This fits the observation of Brown and Stone (2007) that the synergy between public and private actors towards virtuous circles remains underdeveloped. The framework, including the set of interventions, implies that governance actors that regard themselves as central actors need to shift to more modest roles. Setting a provocative ambition is a joint activity. Small wins mainly emerge autonomously, and interventions to activate accumulation processes must be fine-tuned to non-linear dynamics. Governments have no full control on the development and implementation of a provocative ambition. This requires governmental actors to lean backwards and inquire what is ongoing, before acting. Bushe (2011, p. 90) characterises this role as "tracking and fanning...finding and amplifying those innovations they want to nurture, and creating events and processes to energize self-organizing momentum". In addition, the linearrational evaluation methods often applied by governmental actors are no longer suitable for providing balanced judgements on small-wins approaches, and these linear-rational 
methods can even hinder accumulation processes (Termeer and Dewulf, 2018). The evaluation of small wins feeds back into all phases of the policy process where they in turn activate the various propelling mechanism, which illustrates that the small wins governance framework is not neatly organised along the phases of a policy cycle. As such, applying this framework will inevitably clash with the routines, norms and structures of existing governance systems. Hence, governing the acceleration of a linear to a circular economy, requires the continuous transformation of the linearly organised governance system itself.

\section{Conclusions}

This paper aimed to conceptualize mechanisms of transformative change and to use these insights to develop governance interventions to accelerate CE. Therefore, it presented the small wins governance framework. Its main contribution to literature is the explicit targeting of governance interventions to the non-linear mechanisms that accelerate transformation to a CE. This provides strategic interventions, that are more supportive, effective and adaptive, than most existing studies, listing barriers and interventions, and focusing on process interventions only, have offered. The framework is made applicable for research and policy practices by operationalizing the key concepts in tables with characteristics and indicators.

The small-wins perspective intuitively makes sense, but is also criticised with arguments that refer to the persistent belief that small wins are only peanuts. Therefore, we follow Mitchell et al.'s (2012) contention that those evaluating the results of governance interventions must "move away from a focus on the individual outcomes of each small win as a sporadic event towards something potentially transformational as the combined learning experiences of different people in different places head in a similar direction" (Mitchell et al., 2012, p.1063). This requires governance actors to refrain from planning and control, and engage with seeds of transformative change with an attitude of modesty, openness, and ambitious perseverance. For this purpose, they can use all modern and traditional tools, varying from legislation to process facilitation.

The aim of the paper was explorative, but finally, the proof of the pudding is in its eating. Future in-depth empirical analysis must demonstrate to what extent this framework helps to understand and design governance interventions to accelerate the CE. Our frameworks also raises a number of questions that need to be answered through empirical research. For instance, how do the various propelling mechanisms reinforce each other? How to test the argument of Lindblom (1979) that accumulation of small wins might also be the 
fastest way? How to further develop indicators to estimate the potential of small wins to CE? Special attention needs to be paid to the applicability of our approach in different administrative cultures (Biesbroek et al., 2018). Following the review by Ghisellini et al., (2016), the small-wins approach seems to fit very well into the context of the European Union, Japan, and the USA, where the transition towards a CE seems to be occurring mainly as a bottom-up approach (Ghisellini et al., 2016). The top-down approach of the Chinese national strategy, which is based mainly on command-and-control rather than market-based mechanisms, is at first sight less feasible for a small-wins approach (Ghisellini et al., 2016).

Acknowledgements: We thank the policymakers of the Ministry of Infrastructure and Water Management for their collaboration. We thank Art Dewulf and Daniel Wiegant for their contributions to the paper.

Funding: This work was supported by the Dutch Ministry of Infrastructure and Water Management.

\section{References}

Argyris, C., Schön, D.A., 1996. Organizational learning II: Theory, method and practice. Reading, MA, Addison Wesley.

Baez, B., Abolafia, M.Y., 2002. Bureaucratic Entrepreneurship and Institutional Change: a sensemaking approach. J. of Publ. Adm. Res. and Theor. 12 (4)525-552.

Behn, R.D., 2002. The psychological barriers to performance management: Or why isn't everyone jumping on the performance-management bandwagon? Publ. Perf. Manag. Rev. $26(1), 5-25$.

Biedenkopf, K., Van Eynde, S., Bachus, K., 2019. Environmental, climate and social leadership of small enterprises: Fairphone's step-by-step approach. Environ. Polit. 28(1), 43-63, doi : 10.1080/09644016.2019.1521927

Biesbroek, G.R., Lesnikowski, A.J., Ford, J.D., Berrang-Ford, L., Vink, M., 2018. Do Administrative Traditions Matter for Climate Change Adaptation Policy? A Comparative Analysis of 32 High-Income Countries. Rev. of Pol. Res. 35(6).

Biesbroek, G.R., Termeer C.J.A.M., Klostermann, J.E.M., Kabat, P., 2014. Rethinking barriers to adaptation: Mechanism-based explanation of impasses in the governance of an innovative adaptation measure. Glob. Environ. Change. 26(0), 108-118. 
Blomsma, F., Brennan, G., 2017. The emergence of circular economy: A new framing around prolonging resource productivity. J. Ind. Ecol. 21 (3) 603-614.

Brown, S.L., Eisenhardt, K.M., 1997. The art of continuous change: Linking complexity theory and time-paced evolution in relentlessly shifting organizations. Adm. Sci. Q. 42, $1-34$.

Brown, G., Stone, L., 2007. Cleaner production in New Zealand: Taking stock. J. Clean. Prod. 15, 716-728.

Burnes, B., 2004. Kurt Lewin and the planned approach to change: A re-appraisal. J. Man. St. 41(6), 977-1002.

Bushe, G.R., 2011. Appreciative inquiry: Theory and critique. In Boje, D., Burnes, B. and Hassard, J. (eds.) The Routledge Companion To Organizational Change (pp. 87-103). Oxford, UK: Routledge.

Candel, J.J.L., Biesbroek, R., 2016. Toward a processual understanding of policy integration. Pol. Sc., 49(3), 211-231.

Cardoso de Oliveira, M., Machado, M., Chiappetta Jabbour, C., Lopes de Sousa Jabbour, A. 2019. Paving the way for the circular economy and more sustainable supply chains. Man. of Env. Qual. 30(5)1095-1113.

Cooperrider, D.L., Whitney, D., 1999. Appreciative inquiry. San Francisco, BerretKoehler.

Cooperider, D. (2002). Constructing Provocative Propositions. Retrieved from http://appreciativeinquiry.case.edu/practice/toolsPropositionsDetail.cfm?coid=1170.

De Jesus, A., Mendonça, S., 2018. Lost in transition? Drivers and barriers in the ecoinnovation road to the circular economy. Ecol. Econ. 145, 75-89

Domenech, T., Bahn-Walkowiak, B., 2017. Transition towards a resource efficient circular economy in Europe: Policy lessons from the EU and the member states. Ecol. Econ. 3(3). doi: 10.1016/j.ecolecon.2017.11.001

EC (European Commission), 2015. Closing the loop - An EU action plan for the circular economy. Brussels: European Commission. http://eur-lex.europa.eu/legalcontent/EN/TXT/?uri=CELEX:52015DC0614. 
EC (European Commission), 2019. On the implementation of the Circular Economy Action Plan. COM(2019) 190 final. http://ec.europa.eu/environment/circulareconomy/pdf/report implementation 54 actions.pdf

Ellen Macarthur Foundation, 2015. Circularity Indicators. An Approach to Measuring Circularity.

https://www.ellenmacarthurfoundation.org/assets/downloads/insight/CircularityIndicators

Farla, J., Markard, J., Raven, R., Coenen, L., 2012. Sustainability transitions in the making: A closer look at actors, strategies and resources. Technol. Forecast. Soc. Chang. 79(6), 991-998.

Filho, W.L., Platje, J., Gerstlberger, W., Ciegis, R., Kaaria, J., Klavins, M., Kliucininkas, L., 2016. The role of governance in realising the transition towards sustainable societies. $J$. Clean. Prod. 113, 755-766.

Fischer, A., Pascucci, S., 2017. Institutional incentives in circular economy transition. J. Clean. Prod. 155(2), 17-32.

Foster-Fishman, P.G., Watson, E.R., 2012. The ABLe change framework: A conceptual and methodological tool for promoting systems change. Am. J. Commum. Psychol. 49, 503-516.

Galvão, A.G., De Nadae, J., Clemente, D., Chinen, G., De Carvalho, M., 2018. Circular economy: Overview of barriers. Procedia Cirp. 73, 79-85.

doi:10.1016/j.procir.2018.04.011

Garud, R., Kumaraswamy, A., 2005. Vicious and virtuous circles in the management of knowledge: The case of infosys technologies. MIS Q. 29(1), 9-33.

Geels, F., 2011. The multi-level perspective on sustainability transitions: Responses to seven criticism, Env. Innov. and Soc. Trans. 1, 24-40.

Geissdoerfer, M., Savaget, P., Bocken, N.M.P., Hultink, E.J. 2017. The circular economy A new sustainability paradigm? J. Clean. Prod. 143, 757-768.

doi:10.1016/j.jclepro.2016.12.048

Ghisellini, P., Cialani, C., Ulgiati, S., 2016. A review on circular economy: The expected transition to a balanced interplay of environmental and economic systems. J. Clean. Prod. $114,11-32$. 
Goodman, P.S., Dean, J.W., 1982. Creating long-term organizational change. In P.S. Goodman (Ed.), Change in organizations. San Francisco, Jossey-Bass, pp. 226-279.

Grin, J., Rotmans, J., Schot, J., 2010. Transitions towards sustainable development. New York, Routledge.

Haigh, N., Griffiths, A., 2008. A small wins method for addressing climate change and other intractable business issues. Proceedings of Academy of Management 2008 Annual Meeting, Anaheim, California, 8-13 August, 2008. Briarcliff Manor, NY, Academy of Management.

Hekkert, M.P., Suurs, R.A.A., Negro, S.O. , Kuhlmann, S., Smits, R.E.H.M., 2007.

Functions of innovation systems. A new approach for analysing technological change.

Technol. Forecast. and Soc. Change, 74(4), 413-432.

Hobson, K., Lynch, N., 2016. Diversifying and de-growing the circular economy: Radical social transformation in a resource-scarce world. Futures. 82, 15-25.

Jiao, W., Boons, F., 2014. Toward a research agenda for policy intervention and facilitation to enhance industrial symbiosis based on a comprehensive literature review, J. Clean. Prod. 67, 14-25.

Kemp, R., Loorbach, D. and Rotmans, J., 2007. Transition management as a model for managing processes of co-evolution towards sustainable development. Int. J. of Sust. Dev. and World Ec. 14(1)78-91.

Kirchherr, J., Reike, D., Hekkert M., 2017. Conceptualizing the circular economy: An analysis of 114 definitions. Resources, Conservation \& Recycling 127 (2017), 221-232.

Kirchherr, J., Piscicelli, L., Bour, R., Kostense-Smit, E., Muller, J., Huibrechtse-Truijens, A., Hekkert, M., 2018. Barriers to the circular economy: Evidence from the European Union (EU). Ecol. Econ. 150, 264-272.

Klijn, E. H., and Koppenjan, J., 2016. Governance Networks in the Public Sector. Oxon, Routledge.

Korhonen, J., Nuur, C., Feldmann, A., Birkie, S., 2018. Circular economy as an essentially contested concept. J. Clean. Prod. 175, 544-552.

doi:10.1016/j.jclepro.2017.12.111

Lachman, D.A., 2013. A survey and review of approaches to study transitions. Energ. Pol. $58,269-276$.

Levy, A., Merry, U., 1986. Organizational transformation. New York, Praeger. 
Lieder, M., Rashid, A., 2016. Towards circular economy implementation: A comprehensive review in context of manufacturing industry. J. Clean. Prod. 115, 36-51. Lindblom, C.E., 1979. Still muddling, not yet through. Publ. Administr. Rev. 39, 517-526. Loorbach, D., 2014. To Transition! Governance Panarchy in the new Transformation. Inaugural address. Erasmus University Rotterdam.

https://drift.eur.nl/nl/publicaties/transition-governance-panarchy-new-transformation/ Loorbach, D., Frantzeskaki, N., Avelino, F., 2017. Sustainability transitions research: Transforming science and practice for societal change. Annu. Rev. Environ. Resour. 42, 4.1-4.28.

Ma, Y., Lan, J., Thornton, T., Mangalagiu, D., Zhu, D., 2018. Challenges of collaborative governance in the sharing economy: The case of free-floating bike sharing in Shanghai. J. Clean. Prod. 197, 356-365.

McDowall, W., Geng, Y., Huang, B., Barteková, E., Bleischwitz, R., Tưrkeli, S., Doménech, T., 2017. Circular economy policies in China and Europe. J. Ind. Ecol. 21(3), 651-661. Metze, T., 2010. Innovation Ltd. Boundary work in deliberative governance in land use planning. Delft, Eburon.

Metze, T.A.P., Schuitmaker, T.J., Bitsch, L., Broerse, J.E.W., 2017. Breaking barriers for a bio-based economy. Environ. Sci. Pol. 74, 1-7.

Ministry of Infrastructure and the Environment, 2016. A circular economy in the Netherlands by 2050: Government-wide programme for a circular economy. The Hague, Ministry of Infrastructure and the Environment.

Ministry of Infrastructure and Watermanagement, 2019. Uitvoeringsprogramma Circulaire Economie 2019 - 2023 (in Dutch). The Hague, Ministry of Infrastructure and Watermanagement

Mitchell, M., Curtis, A., Davidson, P., 2012. Can triple bottom line reporting become a cycle for "double loop" learning and radical change? J. Account. Audit. Account. 25, 1048-1068.

Nalau, J., Handmer, J., 2015. When is transformation a viable policy alternative? Environ. Sci. Pol. 54, 349-356.

O'Brien, K., 2012. Global environmental change II: From adaptation to deliberate transformation. Progr. Hum. Geogr. 36(5), 667-676. 
O'Connor, J., Keil, M., 2017. The effects of construal level and small wins framing on an individual's commitment to an environmental initiative. J. Environ. Psychol. 52, 1-10. doi:10.1016/j.jenvp.2017.04.010

Orlikowski, W.J., 1996. Improvising organizational transformation over time: A situated change perspective. Inform. Syst. Res. 7, 63-92.

PBL (Planbureau voor de Leefomgeving), 2019. Circulaire economie in kaart. Den Haag, Planbureau voor de Leefomgeving.

Pierson, P. 2004. Politics in time: history, institutions, and social analysis. Princeton, NJ, USA, Princeton University Press.

Plowman, D.A., Baker, L.T., Beck, T.E., Kulkarni, M., Solansky, S.T., Travis, D.V., 2007. Radical change accidentally: The emergence and amplification of small change. Acad. Manag. J. 50(3), 515-543.

Potting, J., Hekkert, M., Worrell, E. and Hanemaaijer A., 2016. Circular Economy: Measuring innovation in product chains. The Hague, PBL Netherlands Environmental Assessment Agency.

Reay, T., Golden-Biddle, K., Germann, K., 2006. Legitimizing a new role: Small wins and microprocesses of change. Acad. Manag. J. 49(5), 977-998.

Rizos, V., Behrens, A., Kafyeke, T., Hirschnitz-Garbers, M., Ioannou, A. 2015. The circular economy: Barriers and opportunities for SMEs. Available at:

https://www.ceps.eu/system/files/WD412GreenEconetSMEsCircularEconomy.pdf Roberts, C., Geels, F, W., Lockwood, M., Newell, P., Schmitz, H., Turnheim, B., Jordan, A., 2018. The politics of accelerating low-carbon transitions: Towards a new research agenda. En. Res, \& Soc. Sc. 44, 304-311.

Roe, E., 2016. Policy messes and their management. Polic. Sci. 49(4), 351-372.

Rogers, E.M. (1983). Diffusion of innovations (3rd ed.). New York, Free Press of Glencoe. Rotmans, J., Kemp, R., van Asselt, M.B.A., 2001. More evolution than revolution: Transition management in public policy. Foresight. 3(1), 15-32.

Singh, J., Ordonez, I., 2016. Resource recovery from post-consumer waste: important lessons for the upcoming circular economy. J. Clean. Prod. 134, 342-353.

Stahel, W.R., 2016. Circular economy. Nature. 53, 435-438. 
Su, B., Heshmati, A., Geng, Y., Yu, X., 2013. A review of the circular economy in China: Moving from rhetoric to implementation. J. Clean. Prod. 42, 215-227.

Termeer, C.J.A.M., Dewulf, A., 2017. Mogelijkheden van de 'small wins' aanpak voor de transitie opgaven van het Ministerie van Infrastructuur en Waterstaat. Research report. Wageningen, Wageningen University. https://library.wur.nl/WebQuery/wurpubs/530708 Termeer, C.J.A.M., Dewulf, A., 2018. A small wins framework to overcome the evaluation paradox of governing wicked problems. Polic. Soc. 8, 289-314.

Termeer, C.J.A.M., Dewulf, A., Biesbroek G.R., 2017. Transformational change: Governance interventions for climate change adaptation from a continuous change perspective. J. Environ. Plann. Manag. 60(4), 558-576.

Turkeli, S., Kemp, R., Huang, B., Bleischwitz, R., McDowall, W., 2018. Circular economy scientific knowledge in the European Union and China: A bibliometric, network and survey analysis (2006-2016). J. Clean. Prod. 197(1), 1244-1261.

Urpelainen, J., 2013. A model of dynamic climate governance: Dream big, win small. Intern. Environ. Agreem. 13, 107-125.

Van Bueren, N.; Demmers, M.; Van der Heijden, R.; Witlox, F. 2016. Towards a Circular Economy: The Role of Dutch Logistics Industries and Governments. Sustainability, 8 , 647.

Van den Bosch, S., Rotmans, J., 2009. Deepening, broadening and scaling up: A framework for steering transition experiments. Delft/Rotterdam, Knowledge Centre for Sustainable System Innovations and Transitions.

Velenturf, A.P.M.; Purnell, P.; Tregent, M.; Ferguson, J.; Holmes, A. 2018. Co-Producing a Vision and Approach for the Transition towards a Circular Economy: Perspectives from Government Partners. Sustainability 10 (5), 1401

Vermaak, H., 2013. Planning deep change through a series of small wins. Paper presented at the Academy of Management Annual Conference, Orlando, FL, August 9-13. Weick, K.E., 1984. Small wins: Redefining the scale of social problems. Amer. Psychol. 39(1), 40-49.

Weick, K.E., 2000. Emergent change as a universal in organizations. In M. Beer and N. Nohria (Eds.), Breaking the code of change. Boston, Harvard Business School, pp. 223243. 
Weick, K.E., Quinn, R., 1999. Organizational change and development. Annu. Rev. Psych. $50,361-386$.

Wells, P., Nieuwenhuis, P., 2018. Over the hill? Exploring the other side of the Rogers' innovation diffusion model from a consumer and business model perspective. J. Clean. Prod. 194, 444-451.

Whicher, A., Harris, C., Beverley, K., Swiatek, P., 2018. Design for circular economy: Developing an action plan for Scotland. J. Clean. Prod. 172, 3237-3248.

Zink, T., Geyer, R., 2017. Circular economy rebound. J. Ind. Ecol. 21(3), 593-602. 


\begin{tabular}{|l|l|l|}
\hline Characteristic & Indicators & Contra-indicators \\
\hline $\begin{array}{l}\text { Represent a desired } \\
\text { future }\end{array}$ & $\begin{array}{l}\text { Affirmative and bold } \\
\text { framing; imagination; gives } \\
\text { a feeling of meaning- } \\
\text { fullness and purpose; } \\
\text { inspires to make it happen }\end{array}$ & $\begin{array}{l}\text { Doom scenarios; emphasis } \\
\text { on what we don't want }\end{array}$ \\
\hline $\begin{array}{l}\text { Help people to stay on } \\
\text { track without hindering } \\
\text { innovativeness }\end{array}$ & $\begin{array}{l}\text { Ambiguity; encouraging a } \\
\text { variety of actors and } \\
\text { actions }\end{array}$ & $\begin{array}{l}\text { Specified goals and } \\
\text { targets; specifying how to } \\
\text { get there }\end{array}$ \\
\hline $\begin{array}{l}\text { Stretch, challenge, and } \\
\text { disrupt the status quo }\end{array}$ & $\begin{array}{l}\text { Explicitly challenging } \\
\text { common assumptions and } \\
\text { routines; exiting but } \\
\text { achievable }\end{array}$ & $\begin{array}{l}\text { Disconnected from the } \\
\text { current situation }\end{array}$ \\
\hline Grounded & $\begin{array}{l}\text { Real-life examples of the } \\
\text { best of current practice }\end{array}$ & Abstract language \\
\hline
\end{tabular}

Table 1: Characteristics and indicators of a provocative ambition 


\begin{tabular}{|l|l|l|}
\hline Characteristic & Indicator & Contra-indicator \\
\hline $\begin{array}{l}\text { Concrete outcomes of } \\
\text { moderate importance }\end{array}$ & $\begin{array}{l}\text { Visible results and lived } \\
\text { experiences; intermediate } \\
\text { results; micro or local level }\end{array}$ & $\begin{array}{l}\text { Promises and ideas only; } \\
\text { fixed best practices; large } \\
\text { scale }\end{array}$ \\
\hline Contribute to a CE & $\begin{array}{l}\text { Clear context specific } \\
\text { narrative of current and } \\
\text { potential contribution; } \\
\text { partly linked to CE } \\
\text { indicators or the ladder of } \\
\text { circularity }\end{array}$ & $\begin{array}{l}\text { No clue; small losses for } \\
\text { many actors }\end{array}$ \\
\hline $\begin{array}{l}\text { In-depth changes } \\
\text { resistance and barriers }\end{array}$ & $\begin{array}{l}\text { Second-order change; } \\
\text { radical new practices } \\
\text { financial and/or regulative } \\
\text { Barriers; faced resistance }\end{array}$ & $\begin{array}{l}\text { Mentioning barriers only; } \\
\text { (too) easily achieved } \\
\text { wins; low hanging fruit }\end{array}$ \\
\hline $\begin{array}{l}\text { Connection technical } \\
\text { and societal change }\end{array}$ & Various modes of synergies & $\begin{array}{l}\text { Technological innovations } \\
\text { only; societal innovation } \\
\text { only }\end{array}$ \\
\hline
\end{tabular}

Table 2: Characteristics and indicators of small wins (based on Termeer and Dewulf, 2018) 


\begin{tabular}{|c|c|c|}
\hline Propelling mechanisms & Indicators & $\begin{array}{l}\text { Examples of interventions } \\
\text { to activate these } \\
\text { mechanisms }\end{array}$ \\
\hline Energizing & $\begin{array}{l}\text { Energy and enthusiasm } \\
\text { Increased commitment } \\
\text { Increased trust }\end{array}$ & $\begin{array}{l}\text { Cherish enthusiasm } \\
\text { Positive framing } \\
\text { Empowerment } \\
\text { Prevent disqualification }\end{array}$ \\
\hline Learning by doing & $\begin{array}{l}\text { More than one } \\
\text { experiment } \\
\text { Feedbacks guide new } \\
\text { experiments } \\
\text { Experimenting also } \\
\text { continues after } \\
\text { disappointing and } \\
\text { unexpected outcomes }\end{array}$ & $\begin{array}{l}\text { Room for experiments } \\
\text { Communities of practice } \\
\text { Improvisation } \\
\text { Tolerance for uncertainties and } \\
\text { disappointments }\end{array}$ \\
\hline Logic of attraction & $\begin{array}{l}\text { Visible success } \\
\text { Commitment of } \\
\text { influential actors triggers } \\
\text { crucial resources } \\
\text { Various communities } \\
\text { know and value wins }\end{array}$ & $\begin{array}{l}\text { Showing the positive } \\
\text { evaluation of small wins in acts } \\
\text { (and not in words only) } \\
\text { Targeting in-side and new } \\
\text { communities }\end{array}$ \\
\hline Bandwagon & Copying good practices & $\begin{array}{l}\text { Highlighting and celebrating } \\
\text { small wins } \\
\text { Storytelling }\end{array}$ \\
\hline Coupling & $\begin{array}{l}\text { Synergy with problems or } \\
\text { aims from other policy } \\
\text { domains } \\
\text { Connections across scales }\end{array}$ & $\begin{array}{l}\text { Organizing new linkages } \\
\text { Demolishing silos } \\
\text { Policy integration and } \\
\text { mainstreaming }\end{array}$ \\
\hline Robustness & $\begin{array}{l}\text { Too numerous } \\
\text { Embedded in practices } \\
\text { Internalized behavioural } \\
\text { change } \\
\text { Non stoppable }\end{array}$ & $\begin{array}{l}\text { No premature termination of } \\
\text { initiatives } \\
\text { Go beyond framing small wins } \\
\text { as pilots } \\
\text { Rearranging existing policies } \\
\text { Institutionalization innovative } \\
\text { practices in formal regulations } \\
\text { Stability in favourable policies }\end{array}$ \\
\hline
\end{tabular}

Table 3. Types of propelling mechanisms with indicators, and examples of related governance interventions (Based on Termeer and Dewulf, 2018) 


\begin{tabular}{|c|c|c|c|}
\hline & Upscaling & Broadening & Deepening \\
\hline WASTED & $\begin{array}{l}\text { In addition to } \\
\text { plastic, an } \\
\text { expansion to other } \\
\text { waste products }\end{array}$ & $\begin{array}{l}\text { Similar projects in } \\
\text { more neighbourhoods } \\
\text { in Amsterdam }\end{array}$ & $\begin{array}{l}\text { Education package to } \\
\text { reprocess locally } \\
\text { recycled plastic waste } \\
\text { Adding other social, } \\
\text { environmental, and } \\
\text { economic values to the } \\
\text { neighbourhood } \\
\text { From recycling to reuse }\end{array}$ \\
\hline Bundles & $\begin{array}{l}\text { More appliances in } \\
\text { more households } \\
\text { in more countries }\end{array}$ & $\begin{array}{l}\text { Expanding services to } \\
\text { other appliance } \\
\text { categories (e.g. } \\
\text { coffee) and other } \\
\text { sustainability goals } \\
\text { (reduce water use) }\end{array}$ & $\begin{array}{l}\text { Manufacturers redesign } \\
\text { appliances that last } \\
\text { longer and can be } \\
\text { repaired }\end{array}$ \\
\hline $\begin{array}{l}\text { Circular } \\
\text { procurement }\end{array}$ & $\begin{array}{l}\text { Expanding to all } \\
\text { stewards' } \\
\text { workwear and } \\
\text { finally to standard } \\
\text { uniforms }\end{array}$ & $\begin{array}{l}\text { Applying circular } \\
\text { procurement lessons } \\
\text { to other products } \\
\text { (furniture, buildings, } \\
\text { etc.) }\end{array}$ & $\begin{array}{l}\text { Rethinking purchasing, } \\
\text { including annual } \\
\text { budgets and accounts, } \\
\text { partners, risks } \\
\text { management, } \\
\text { embeddedness in } \\
\text { organisation, etc. }\end{array}$ \\
\hline $\begin{array}{l}\text { Ban on free } \\
\text { plastic bags }\end{array}$ & Fewer exceptions & $\begin{array}{l}\text { Ban on other plastic } \\
\text { products, such as } \\
\text { throwaway cutlery }\end{array}$ & $\begin{array}{l}\text { General ban on plastic } \\
\text { bags in some } \\
\text { supermarkets } \\
\text { Ideas for plastic-free } \\
\text { municipalities }\end{array}$ \\
\hline
\end{tabular}

Table 4: Examples of upscaling, broadening, and deepening small wins in the four initiatives 